\title{
Co-Immobilization of Tri-Enzymes for the Conversion of Hydroxymethylfurfural to 2,5-Diformylfuran
}

\author{
Zhuofu Wu®, Linjuan Shi, Xiaoxiao Yu, Sitong Zhang and Guang Chen *
}

Key Laboratory of Straw Biology and Utilization, The Ministry of Education, College of Life Science, Jilin Agricultural University, Changchun 130118, China; wzf@jlau.edu.cn (Z.W.); linjuanshi84@gmail.com (L.S.); xiaoxiaoyu094@gmail.com (X.Y.); sitongzhang20@gmail.com (S.Z.)

* Correspondence: guangc61@gmail.com; Tel.: +86-431-8453-2942

Received: 2 September 2019; Accepted: 9 October 2019; Published: 10 October 2019

\begin{abstract}
Acting as a "green" manufacturing route, the enzyme toolbox made up of galactose oxidase, catalase, and horseradish peroxidase can achieve a satisfactory yield of 2,5-diformylfuran derived from $30 \mathrm{mM}$ hydroxymethylfurfural. However, as the concentration of hydroxymethylfurfural increases, the substrate causes oxidative damage to the activity of the tri-enzyme system, and the accumulated hydrogen peroxide produced by galactose oxidase causes tri-enzyme inactivation. The cost of tri-enzymes is also very high. These problems prevent the utilization of this enzyme toolbox in practice. To address this, galactose oxidase, catalase, and horseradish peroxidase were co-immobilized into $\mathrm{Cu}_{3}\left(\mathrm{PO}_{4}\right)_{2}$ nanoflowers in this study. The resulting co-immobilized tri-enzymes possessed better tolerance towards the oxidative damage caused by hydroxymethylfurfural at high concentrations, as compared to free tri-enzymes. Moreover, the 2,5-diformylfuran yield of co-immobilized tri-enzymes $(95.7 \pm 2.7 \%)$ was 1.06 times higher than that of separately immobilized enzymes $(90.4 \pm 1.9 \%)$. This result could be attributed to the boosted protective effect provided by catalase to the activity of galactose oxidase, owing to the physical proximity between them on the same support. After 30 recycles, co-immobilized tri-enzymes still achieves $86 \%$ of the initial yield. Moreover, co-immobilized tri-enzymes show enhanced thermal stability compared with free tri-enzymes. This work paves the way for the production of 2,5-diformylfuran from hydroxymethylfurfural via co-immobilized tri-enzymes.
\end{abstract}

Keywords: co-immobilization; hydroxymethylfurfural; 2,5-diformylfuran; galactose oxidase; catalase; horseradish peroxidase

\section{Introduction}

It is well known that hydroxymethylfurfural (HMF) is formed by the dehydration of $\mathrm{C}_{6}$ sugars produced from lignocellulosic biomass [1,2]. HMF was also mentioned in the US Department of Energy's "Top 10" list of promising platform chemicals [3]. As an important oxidized derivative of HMF, 2,5-diformylfuran (DFF) has been used as the starting material for synthesizing a host of new products, such as antifungal agents [4], pharmaceuticals [5], macrocyclic ligands [6], metal-organic compounds [7], furan-containing polymers [8,9], and cross-linking agents for poly (vinyl alcohol) [10,11], hence, the selective oxidation of HMF to DFF has received increased attention recently [12].

So far, a variety of chemical oxidants have been employed for the synthesis of DFF from HMF. For instance, the application of a DMSO-potassium dichromate complex affords a $75 \%$ yield of DFF under ultrasonic irradiation at ambient temperature [13]. An oxidation reaction of HMF to DFF driven by $\mathrm{Mn}$ (III)-salen catalysts provides DFF at an $89 \%$ yield in $\mathrm{pH} 11.3$ buffered medium at room temperature [14]. The utilization of a polymer-supported IBX amide gives DFF an $87 \%$ yield in chloroform solution [15]. The maximum observed yield of DFF is $57 \%$ with $\mathrm{Co} / \mathrm{Mn} / \mathrm{Zr} / \mathrm{Br}$ as a catalyst 
at 1 bar oxygen pressure [16]. Up to 82\% HMF conversion and DFF $99 \%$ selectivity was obtained by immobilized vanadyl-pyridine complexes at $130{ }^{\circ} \mathrm{C}$ [17]. The maximum HMF conversion of $84 \%$ and selectivity of $97 \%$ was obtained using vanadyl phosphate catalysts at $150{ }^{\circ} \mathrm{C}$ [18]. $\mathrm{Cu}\left(\mathrm{NO}_{3}\right)_{2} / \mathrm{VOSO}_{4}$ can show 99\% HMF conversion and 99\% DFF selectivity at $80^{\circ} \mathrm{C}$ for $1.5 \mathrm{~h} \mathrm{[19].} \mathrm{Although} \mathrm{the} \mathrm{usage} \mathrm{of}$ the abovementioned chemical oxidants gives relatively satisfactory DFF yields and selectivity, their use often pollutes the environment owing to the requirement for harsh reaction conditions and the utilization of metal salts and organic solvents. Alternatively, the enzyme catalysis route requires only mild conditions and obviates the usage of toxic chemicals, and thus represents a desirabke "green" manufacturing strategy for DFF production [20,21].

Regrettably, studies into using enzymes as catalysts to accomplish the conversion of HMF to DFF are relatively rare. Although chloroperoxidase and hydrogen peroxide catalyze the oxidation of $\mathrm{HMF}$ to obtain a maximum $74 \%$ selectivity and $87 \%$ conversion to DFF, two main side products, 2,5-furandicarboxylic acid and 5-formyl-2-furancarboxylic acid, can be detected in the reaction medium, which can be obstacles to the separation of DFF [22]. The enzyme toolbox selected in this study, containing galactose oxidase, catalase, and horseradish peroxidase, offers DFF at a 91\% yield and almost $100 \%$ selectivity using $30 \mathrm{mM} \mathrm{HMF}$ as feedstock in deionized water at $25{ }^{\circ} \mathrm{C}$ for $96 \mathrm{~h} \mathrm{[23].}$ Among the three enzymes, galactose oxidase plays an essential role in the oxidation of DFF [24]. Catalase decomposes $\mathrm{H}_{2} \mathrm{O}_{2}$ generated in the synthesis solution, providing protection for the galactose oxidase [25]. Horseradish peroxidase activates the oxidation activity of galactose oxidase by forming intramolecular crosslinks via o,o-dityrosine [26]. As a result, galactose oxidase acts synergistically with catalase and horseradish peroxidase in performing the oxidation of HMF to DFF (Scheme 1). However, the high cost of the three enzymes, the oxidative damage to the three enzymes caused by HMF at a high concentration $[27,28]$, and the inactivation of the activities of the three enzymes brought about by the accumulation of hydrogen peroxide generated in the presence of a high concentration of $\mathrm{HMF}$ impede the large scale production of DFF.

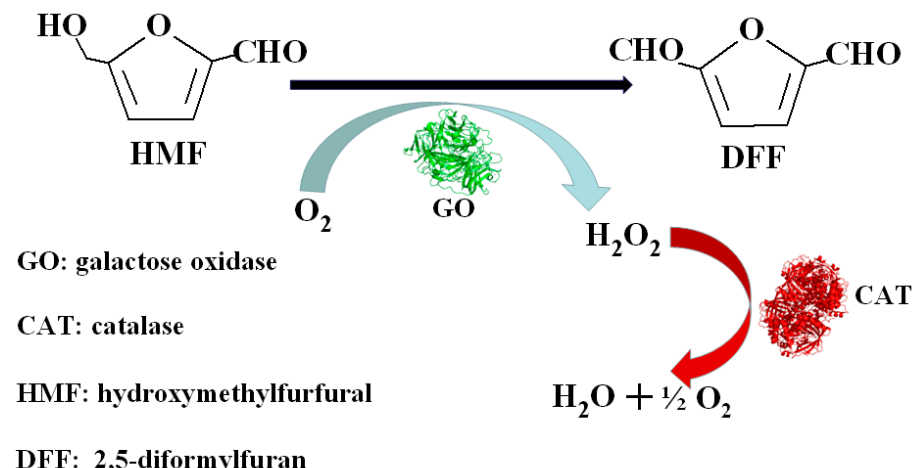

Scheme 1. The oxidation of HMF from DFF catalyzed by enzymes.

It is well established that immobilization of enzymes is a straightforward strategy to overcome the low operational stability of enzymes, and the difficulties in their recycling [29]. In 2012, Zare et al. accidently discovered the formation of hybrid organic and inorganic nanoflowers through self-assembly of various proteins and copper phosphate crystals under mild conditions [30]. The coordination of the nitrogen atoms in the proteins and the $\mathrm{Cu}$ ion in the nanoflowers led to the formation of hybrid nanoflowers. As the enzyme was used as the organic component, the harvested hybrid nanoflowers take on boosted enzymatic activity and stability. The mild conditions required for preparing the hybrid nanoflowers guarantee that the conformation of the enzyme is not perturbed during self-assembly, allowing it to retain its maximum catalytic activity. The high surface area of the hybrid nanoflowers facilitates the diffusion of the substrate and product to and from the active site of the enzyme, so that it exerts enzymatic activity in the matrix. The substantial mechanical stability of the nanoflower matrix is beneficial to the utilization of the enzyme in repeated batches and in continuous operation. Therefore, 
this method was adopted in this work to solve the problem arising from the use of the three enzymes involved in the oxidation reaction of HMF at a high concentration.

It is the case, generally speaking, that immobilizations of multiple enzymes can be classified into two types: (1) all the enzymes are simultaneously immobilized on the same carrier, namely co-immobilization, and (2) each enzyme is independently immobilized on the carrier under their respective optimal immobilization conditions, and then the resulting separately immobilized enzymes are used together. The usage and preparation of co-immobilized enzymes are relatively complex. When all involved enzymes are immobilized on the same carrier under the identical conditions, this immobilization protocol is often non-ideal for all enzymes possessing its unique function and structure, respectively. Moreover, the difference in the stability between different enzymes raises another serious problem: as the least stable enzyme lost its activity, the half live of the whole co-immobilized multi-enzyme system shall be reduced dramatically, bringing about that the whole co-immobilized multi-enzyme system must be discarded even if the more stable enzyme in this system still maintains full activity [31]. Hence, immobilization is a non-trivial protocol for fabricating the biocatalysts. In Roberto and his colleagues' work, the more stable enzyme was firstly immobilized on the glyoxyl support by covalent attachment, and then the least stable enzyme was immobilized on the same carrier by interfacial activation. The least stable enzyme can be released from the carrier by using detergents after its activity dramatically decreases, and then the glyoxyl support loaded with the more stable enzyme was employed to reload the fresh batch of the least stable enzyme. Using this sequential co-immobilization method, the more stable enzymes in co-immobilized multi-enzyme systems can be reused [32-35]. Although the co-immobilization of enzymes has its issues, this technique plays a critical role in certain cases in which it is necessary to achieve a rapid conversion or elimination of the reaction intermediates. As compared with separately immobilized enzymes, co-immobilized enzymes have kinetic advantages in a cascade reaction [31]. The spatial distance between the active sites of the different enzymes immobilized on the same carrier is shorter than in separately immobilized enzymes, which facilitates the efficient shuttling of the reaction intermediates in the cascade reaction, and thus brings about an improvement in reaction velocity $[31,36]$. These intermediates either affect the yield of the final product, or inactivate the activity of all the enzymes involved [37-41]. For instance, as co-immobilized tri-enzymes are comprised of glycerol dehydrogenase, NADH oxidase and catalase were employed to produce 1,3-dihydroxyacetone. The in situ decomposition of $\mathrm{H}_{2} \mathrm{O}_{2}$ catalyzed by catalase avoids the spontaneous oxidation of glycerol dehydrogenase and NADH oxidase, and thus markedly enhances the yield of 1,3-dihydroxyacetone [42].

Inspired by previous published work, to address problems in the oxidation of HMF, in this work enzyme co-immobilization technology was adopted because of the following reasons: (I) the enhanced rigidity of enzyme conformation via immobilization would lead to improved tolerance of the three enzymes towards the inactivation effect of HMF at a high concentration due to the multiple attachments between the enzymes and the carrier $[29,43,44]$; (II) the proximity effect offered by co-immobilized enzymes should be of benefit by weakening the toxic effect of hydrogen peroxide on the three enzymes during the oxidation reaction, by rapidly eliminating the hydrogen peroxide produced in the presence of a high concentration of HMF [40-42]; (III) the co-immobilization of enzymes would enable the reuse of the three enzymes, to reduce the cost in DFF production.

In this study, galactose oxidase, catalase and horseradish peroxidase were co-immobilized into $\mathrm{Cu}_{3}\left(\mathrm{PO}_{4}\right)_{2}$ nanoflower matrixes possessing perfect mechanical stability and a high surface area [30], and then the obtained co-immobilized tri-enzymes were employed in the conversion of HMF at a high concentration to DFF (Scheme 2). SEM and FTIR were employed to characterize the co-immobilized tri-enzymes. The activity and kinetic parameters of free tri-enzymes and co-immobilized tri-enzymes were assayed. The reaction conditions and the concentration of HMF, temperature and $\mathrm{pH}$ were optimized. A comparison between co-immobilized tri-enzymes and independently immobilized enzymes in terms of DFF yield was carried out. A comparison in thermal stability between free tri-enzymes and co-immobilized tri-enzymes was also undertaken. Then, co-immobilized tri-enzymes 
were conducted in successive batches. Finally, the level of $\mathrm{H}_{2} \mathrm{O}_{2}$ produced by free tri-enzymes, co-immobilized tri-enzymes, and separately immobilized enzymes was investigated and compared.

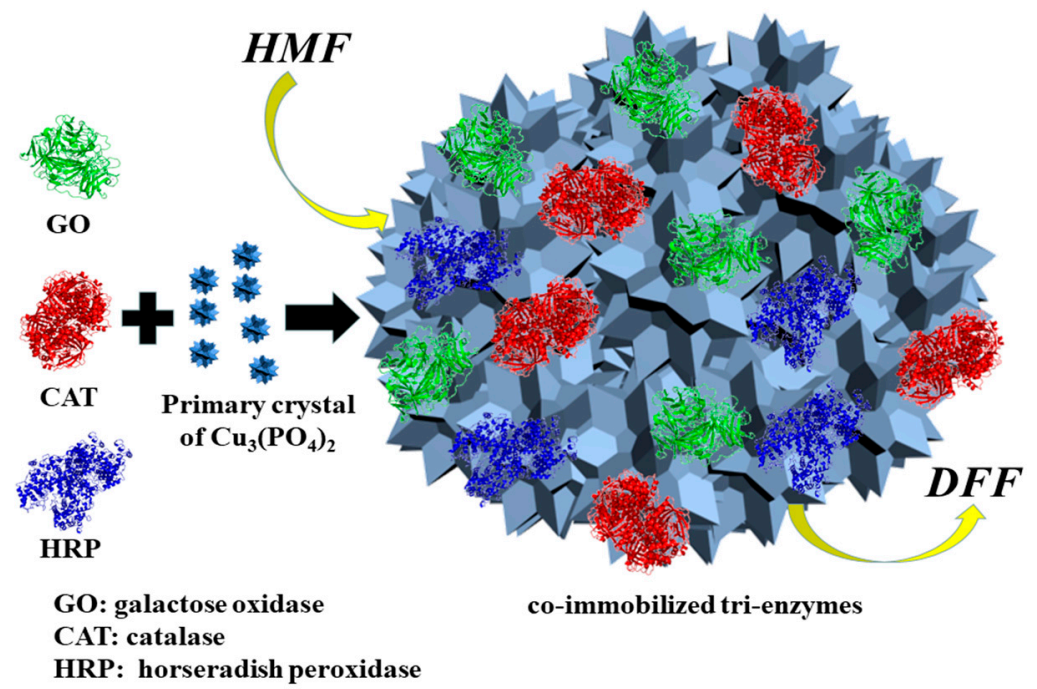

Scheme 2. The conversion of HMF to DFF catalyzed by co-immobilized tri-enzymes.

\section{Results and Discussion}

\subsection{SEM Images of Co-Immobilized Tri-Enzymes}

Enzymes incorporated into nanoflowers possess nanostructures with branched morphologies, as shown in Figure 1. The average size of these nested structures is in the range of 3-8 nm. The appearance of porous flower-like structures with nanoscale feature depends on the aggregation of a number of primary nanoparticles made of copper (II) phosphorus bound by a protein's amine groups [30]. This nanostructure, with a much higher surface area, enables the enzyme substrate to easily access its active site during the oxidation reaction.
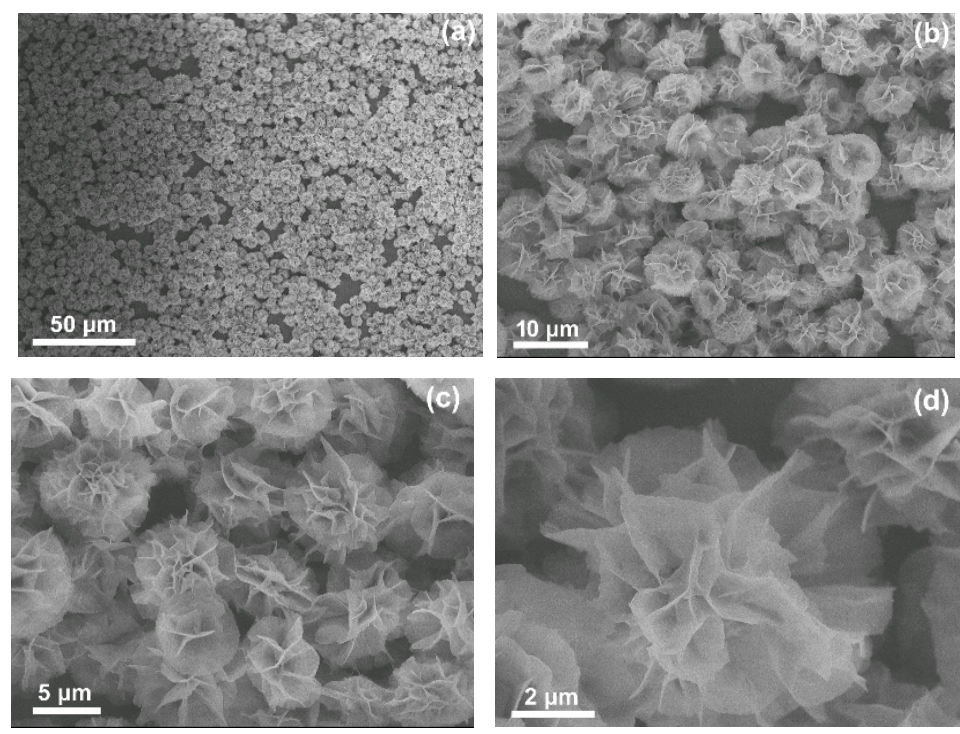

Figure 1. SEM images of the co-immobilized tri-enzymes with different enlargement factors (a-d).

\subsection{FTIR Spectra of Co-Immobilized Tri-Enzymes}

The FTIR spectra of enzymes, co-immobilized tri-enzymes and $\mathrm{Cu}_{3}(\mathrm{PO})_{4}$ crystals are plotted in Figure 2. The spectrum of $\mathrm{Cu}_{3}(\mathrm{PO})_{4}$ crystals in a curve A presents the characteristic absorption 
of $(\mathrm{PO})_{4}^{-3}$ at $1035 \mathrm{~cm}^{-1}$ and $556 \mathrm{~cm}^{-1}$ [45], and the spectrum of tri-enzymes in curve $\mathrm{C}$ shows the corresponding characteristic absorption of amide I and II bands of protein at $1660 \mathrm{~cm}^{-1}$ and $1533 \mathrm{~cm}^{-1}$, respectively [46]. Most importantly, the spectrum of co-immobilized tri-enzymes in curve B exhibits the characteristic absorption of both $(\mathrm{PO})_{4}{ }^{-3}$ of $\mathrm{Cu}_{3}(\mathrm{PO})_{4}$ crystals and amide I and II bands of protein, respectively. Hence, it is can be concluded from the presented spectra that the tri-enzymes are present in the nanoflowers.

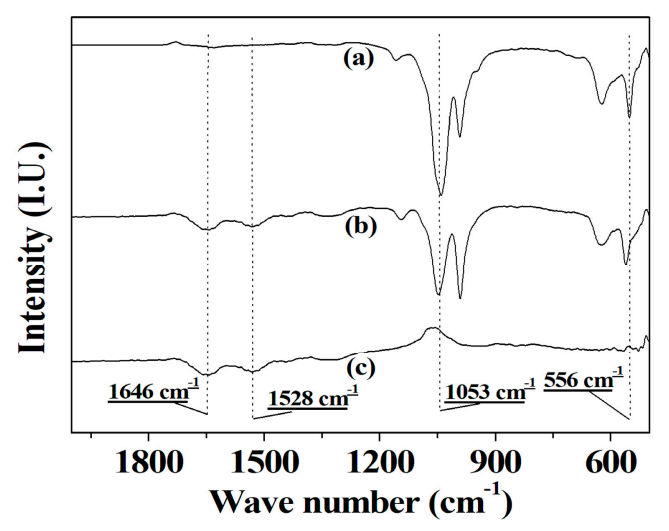

Figure 2. FTIR spectra of $\mathrm{Cu}_{3}(\mathrm{PO})_{4}$ crystal (a), co-immobilized tri-enzymes (b) and tri-enzymes (c).

\subsection{Optimization of the Proportion of Enzymes}

Before co-immobilization, the proportion of the three enzymes used was screened on the basis of the value of DFF yield and the level of $\mathrm{H}_{2} \mathrm{O}_{2}$ produced from the oxidation of $\mathrm{HMF}(\mu \mathrm{M})$. From Table 1 , the DFF yield significantly increases with the increase of the GA/CAT/HRP ratio, ranging from $0.2 / 400 / 25$ to $1.0 / 400 / 25$. As the GA/CAT/HRP ratio is $1.0 / 400 / 25$, the resulting co-immobilized enzymes give $64.5 \pm 2.3 \%$ in DFF yield, and $4.9 \pm 0.3 \mu \mathrm{M}$ of $\mathrm{H}_{2} \mathrm{O}_{2}$ concomitantly formed from the oxidation of $\mathrm{HMF}$ could be found in the reaction mixture. With the further increase of the GA/CAT/HRP ratio, the increase of the DFF yield slows, while the level of $\mathrm{H}_{2} \mathrm{O}_{2}$ accumulated in the reaction medium rapidly rises. Therefore, a GA/CAT/HRP ratio of 1.0/400/25 was used in the following co-immobilization procedure.

Table 1. The optimization of the proportion of enzymes added to the co-immobilization system.

\begin{tabular}{ccc}
\hline $\begin{array}{c}\text { Unit Ratio of GA/CAT/HRP } \\
\text { Used }^{\text {a }}\end{array}$ & Yield (\%) & $\begin{array}{c}\text { Concentration of } \mathbf{H}_{\mathbf{2}} \mathbf{O}_{\mathbf{2}} \text { Produced } \\
\text { from the Oxidation of } \mathbf{H M F}(\boldsymbol{\mu m})\end{array}$ \\
\hline $0.2 / 400 / 25$ & $44.8 \pm 1.8$ & $\mathrm{ND}$ \\
$0.5 / 400 / 25$ & $56.2 \pm 2.8$ & $\mathrm{ND}$ \\
$1.0 / 400 / 25$ & $64.5 \pm 2.3$ & $4.9 \pm 0.3$ \\
$2.0 / 400 / 25$ & $66.1 \pm 2.2$ & $40.7 \pm 0.3$ \\
$4.0 / 400 / 25$ & $66.4 \pm 1.9$ & $92.9 \pm 0.4$ \\
\hline
\end{tabular}

${ }^{\text {a }}$ Reaction conditions: deionized water; $25^{\circ} \mathrm{C}$; at $250 \mathrm{mM}$ HMF.

\subsection{Comparison of Activity}

Because the self-assembly of hybrid organic-inorganic nanoflowers was conducted under mild conditions, which minimizes enzyme denaturation [30], most of the activities of the three enzymes were preserved after co-immobilization (Table 2). 
Table 2. Comparison of activity of free enzymes, co-immobilized enzymes, and independently immobilized enzymes.

\begin{tabular}{cc}
\hline Samples & Activity $^{\mathbf{a}} \mathbf{( \mathbf { U ~ } \mathbf { ~ } ^ { \mathbf { 1 } } \mathbf { ) }}$ \\
\hline Free galactose oxidase & $166.1 \pm 3.2$ \\
Galactose oxidase in co-immobilized tri-enzymes & $159.2 \pm 2.7$ \\
Independently immobilized galactose oxidase & $157.4 \pm 2.1$ \\
Free catalase & $2270.5 \pm 29.4$ \\
Catalase in co-immobilized tri-enzymes & $2245.3 \pm 24.3$ \\
Independently immobilized catalase & $2258.6 \pm 28.7$ \\
Free horseradish peroxidase & $3658.2 \pm 34.2$ \\
Horseradish peroxidase in co-immobilized tri-enzymes & $3583.9 \pm 42.3$ \\
Independently immobilized horseradish peroxidase & $3547.7 \pm 36.1$ \\
\hline
\end{tabular}

${ }^{a}$ Activity refers to the amount of product formed per minute per milligram of protein.

\subsection{Kinetic Parameters Analysis}

Owing to the mild synthetic route for synthesizing the protein-incorporated nanoflowers [30], here the catalytic behavior of the three enzymes did not obviously change after co-immobilization or separate immobilization (Table 3).

Table 3. Comparison of the kinetic parameters of free enzymes, co-immobilized enzymes, and independently immobilized enzymes.

\begin{tabular}{ccc}
\hline Parameter & $\mathbf{K m ~} \mathbf{( m \mathbf { M } )}$ & $\boldsymbol{V} \mathbf{m a x}\left(\boldsymbol{\mu \mathbf { m o l }} \mathbf{~ m i n}^{\mathbf{- 1}} \mathbf{~ m g}^{\mathbf{- 1}}\right)$ \\
\hline Free galactose oxidase & $17.6 \pm 1.3$ & $216.4 \pm 5.7$ \\
Galactose oxidase in co-immobilized tri-enzymes & $17.8 \pm 1.6$ & $207.3 \pm 3.1$ \\
Independently immobilized galactose oxidase & $17.4 \pm 1.7$ & $205.6 \pm 4.7$ \\
Free catalase & $26.9 \pm 0.1$ & $7218.6 \pm 26.4$ \\
Catalase in co-immobilized tri-enzymes & $25.2 \pm 0.1$ & $7015.4 \pm 26.6$ \\
Independently immobilized catalase & $26.3 \pm 0.5$ & $7183.8 \pm 89.5$ \\
Free horseradish peroxidase & $2.21 \pm 0.04$ & $4377.7 \pm 28.4$ \\
Horseradish peroxidase in co-immobilized tri-enzymes & $2.12 \pm 0.03$ & $4356.8 \pm 25.2$ \\
Independently immobilized horseradish peroxidase & $2.15 \pm 0.06$ & $4334.2 \pm 31.8$ \\
\hline
\end{tabular}

\subsection{Screening of Reaction Conditions}

The effect of the concentration of HMF, temperature and $\mathrm{pH}$ on DFF yield was investigated to optimize the reaction parameters.

\subsubsection{Effect of HMF Concentration}

In practice, the oxidation reaction of HMF is implemented at a high concentration. Therefore, the effect of HMF concentration in the range of $50-400 \mathrm{mM}$ on the DFF yield was surveyed. The amount of tri-enzymes loaded into the hybrid nanoflowers added to the reaction media was equal to the amount of free tri-enzymes used to evaluate whether the resistance of tri-enzymes towards the oxidative damage derived from HMF at a high concentration could be enhanced after immobilization. As for co-immobilized tri-enzymes, the DFF yield slightly decreases at a low HMF concentration ranging from 50 to $200 \mathrm{mM}$, and thereafter the DFF yield begins to drop significantly with an increasing concentration of HMF in the range of 200 to $400 \mathrm{mM}$ (Figure 3a). For free tri-enzymes, DFF yield rapidly declines with the increase of the HMF concentration (Figure $3 b$ ). The results indicate that co-immobilized tri-enzymes show better tolerance towards the oxidative damage caused by HMF as compared with free tri-enzymes, suggesting that the stability of tri-enzymes is boosted via immobilization. Herein, co-immobilized enzymes still achieve a good DFF yield (78.5\%) at $200 \mathrm{mM} \mathrm{HMF}$ concentration, which was employed in the subsequent study. 


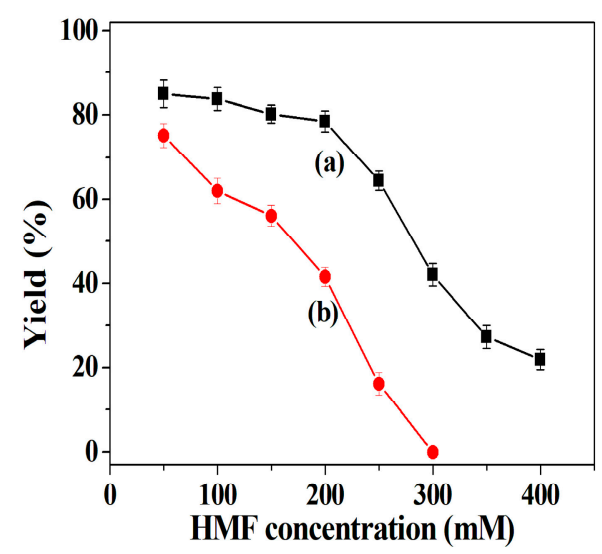

Figure 3. Effect of HMF concentration on DFF yield: co-immobilized tri-enzymes (a) and free tri-enzymes (b). Reaction conditions: deionized water; $25^{\circ} \mathrm{C}$; at different $\mathrm{HMF}$ concentrations from $50 \mathrm{mM}$ to $400 \mathrm{mM}$. Free tri-enzymes ( $20 \mathrm{U}$ of galactose oxidase, $8000 \mathrm{U}$ of catalase and $500 \mathrm{U}$ of horseradish peroxidase) and $35 \mathrm{mg}$ of co-immobilized tri-enzymes were utilized in parallel experiments, respectively.

\subsubsection{Effect of $\mathrm{pH}$}

Considering that a change in $\mathrm{pH}$ can influence the activity of enzymes, the dependence of DFF yield upon $\mathrm{pH}$ in the range of 5.0-8.0 was evaluated here. Figure 4 illustrates that DFF yield of co-immobilized tri-enzymes and separately immobilized tri-enzymes increased with an increasing $\mathrm{pH}$ value from 5.0 to 6.6, and then decreased as $\mathrm{pH}$ increased further. In the case of free tri-enzymes, DFF yield gradually increased with increasing $\mathrm{pH}$ in the range 5.5-7.1, but after 7.1 DFF yield decreased. The maximum yields of co-immobilized tri-enzymes and separately immobilized tri-enzymes were observed at $\mathrm{pH}$ 6.6, while free tri-enzymes showed a maximum yield at $\mathrm{pH} 7.1$, which is close to the optimal pH (7.0-7.3) of galactose oxidase [47]. The tri-enzymes showed a shift in the optimal $\mathrm{pH}$ of 0.6 units toward the acidic region after immobilization, which may be attributed to the partitioning of protons influenced by $\mathrm{Cu}$ ions in the nanoflower matrix, and the mass transfer limitation of HMF [48]. In the subsequent study, oxidation reactions of co-immobilized tri-enzymes and separately immobilized tri-enzymes were carried out in Tris- $\mathrm{HCl}$ buffer $(50 \mathrm{mM}, \mathrm{pH}$ 6.6), and for free tri-enzymes in Tris- $\mathrm{HCl}$ buffer (50 mM, pH 7.1), respectively.

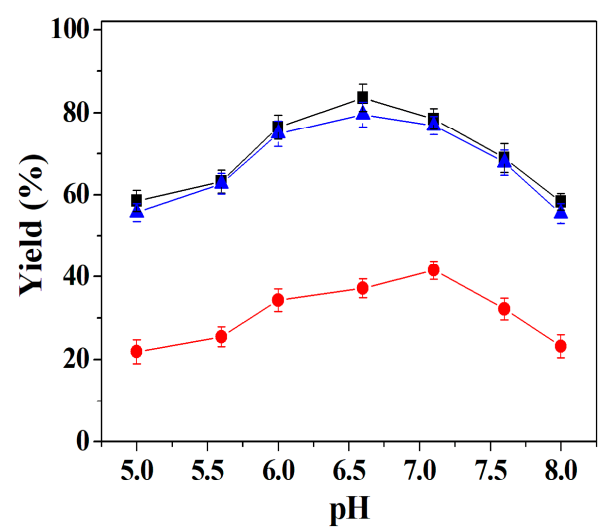

Figure 4. Effect of $\mathrm{pH}$ on the yield of DFF of co-immobilized tri-enzymes ( $\mathbf{\square})$, separately immobilized tri-enzymes $(\mathbf{\Delta})$, and free tri-enzymes $(\bullet)$. Reaction conditions: $35 \mathrm{mg}$ of co-immobilized tri-enzymes or $105 \mathrm{mg}$ of separately immobilized tri-enzymes (containing $35 \mathrm{mg}$ of immobilized galactose oxidase, $35 \mathrm{mg}$ of immobilized catalase and $35 \mathrm{mg}$ of immobilized horseradish peroxidase) or free tri-enzymes (20 U of galactose oxidase, $8000 \mathrm{U}$ of catalase and $500 \mathrm{U}$ of horseradish peroxidase); $200 \mathrm{mM}$ of HMF; $25^{\circ} \mathrm{C}$; at different $\mathrm{pH}$ values ranging from 5.0 to 8.0. The buffers used were citric acid-sodium citrate (pH 5.0-6.6), and Tris- $\mathrm{HCl}$ (pH 7.1-8.0), respectively. 


\subsubsection{Effect of Temperature}

The temperature is an important parameter for the properties of enzymes [49-52]. The DFF yield was studied as a function of temperature ranging from $15-45^{\circ} \mathrm{C}$. Figure 5 shows that the DFF yield of co-immobilized tri-enzymes and separately immobilized tri-enzymes increased with the increase of the temperature between 15 and $37^{\circ} \mathrm{C}$, while DFF yield dropped with a further increase of the temperature between 37 and $45^{\circ} \mathrm{C}$. In a free tri-enzymes solution, DFF yield gradually increased at lower temperatures from 15 to $37^{\circ} \mathrm{C}$, and then it dropped significantly at higher temperatures exceeding $37^{\circ} \mathrm{C}$. Above $37^{\circ} \mathrm{C}$, in all three cases, the fall in the DFF yield can be ascribed to the inactivation of the enzymes. The results signify that the optimal yield of co-immobilized tri-enzymes, separately immobilized tri-enzymes, and free tri-enzymes occurred at $37^{\circ} \mathrm{C}$, which was adopted in the following study.

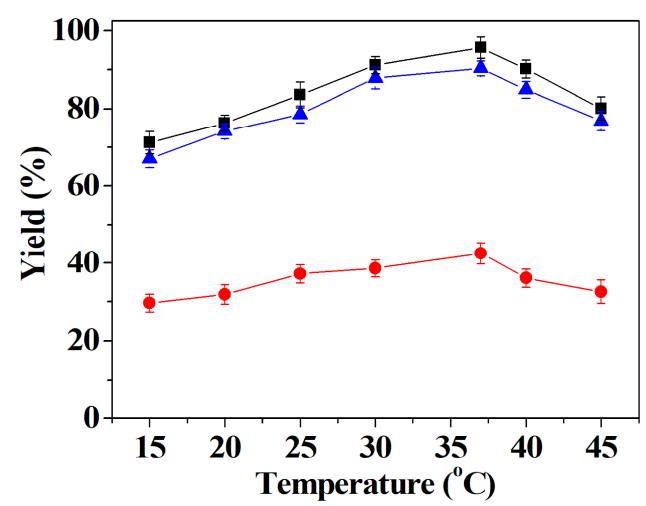

Figure 5. Effect of temperature on the DFF yield of co-immobilized tri-enzymes ( $\mathbf{\square})$, separately immobilized tri-enzymes $(\boldsymbol{\Lambda})$ and free tri-enzymes $(\boldsymbol{\bullet})$. Reaction conditions: $35 \mathrm{mg}$ of co-immobilized tri-enzymes or $105 \mathrm{mg}$ of separately immobilized tri-enzymes (containing $35 \mathrm{mg}$ of immobilized galactose oxidase, $35 \mathrm{mg}$ of immobilized catalase and $35 \mathrm{mg}$ of immobilized horseradish peroxidase) or free tri-enzymes (20 U of galactose oxidase, $8000 \mathrm{U}$ of catalase and $500 \mathrm{U}$ mg of horseradish peroxidase); $200 \mathrm{mM}$ of HMF; Tris-HCl buffer ( $50 \mathrm{mM}, \mathrm{pH}$ 6.6) for co-immobilized tri-enzymes and separately immobilized tri-enzymes, and Tris- $\mathrm{HCl}$ buffer $(50 \mathrm{mM}, \mathrm{pH} 7.1)$ for free tri-enzymes; at different temperatures ranging from 15 to $45^{\circ} \mathrm{C}$.

\subsection{Thermal Stability}

To compare the difference in structural stability among free tri-enzymes, co-immobilized tri-enzymes, and separately immobilized tri-enzymes, heat inactivation experiments were conducted in the temperature range of $35-75{ }^{\circ} \mathrm{C}$. Figure 6 shows that although the relative DFF yields of the three samples declined with the increasing treatment temperature, the decline rates of the relative DFF yields of co-immobilized tri-enzymes and separately immobilized tri-enzymes were much slower than that of the free tri-enzymes. The results also indicate that the relative DFF yield of free tri-enzymes is zero percent beyond $70{ }^{\circ} \mathrm{C}$, while co-immobilized tri-enzymes afford $59.8 \pm 3.2 \%$ and $49.8 \pm 2.9 \%$ of relative DFF yield at 70 and $75^{\circ} \mathrm{C}$, respectively, and separately immobilized tri-enzymes exhibit $59.7 \pm 2.4 \%$ and $48.6 \pm 2.1 \%$ of relative DFF yield at 70 and $75^{\circ} \mathrm{C}$, respectively. The substantial improvement in the thermal stability of co-immobilized tri-enzymes and separately immobilized tri-enzymes can be ascribed to the enhancement of the rigidification of the tri-enzymes' tertiary structure, caused by the coordination bond between the amide groups in the tri-enzyme backbone and $\mathrm{Cu}$ ions in the hybrid nanoflowers $[30,53]$. The results also suggest that there is no significant difference in thermal stability between tri-enzymes co-immobilized into the nanoflowers and tri-enzymes separately immobilized into the nanoflowers. 


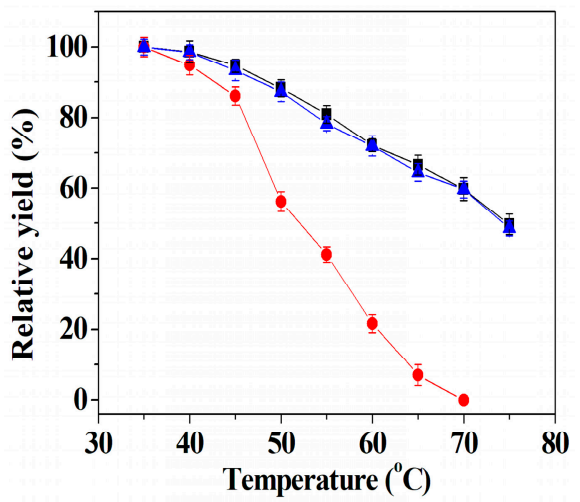

Figure 6. The effect of heat incubation on the DFF yield of co-immobilized tri-enzymes ( $\boldsymbol{\square})$, separately immobilized tri-enzymes $(\boldsymbol{\Lambda})$ and free tri-enzymes $(\bullet)$. Reaction conditions: $35 \mathrm{mg}$ of co-immobilized tri-enzymes or $105 \mathrm{mg}$ of separately immobilized tri-enzymes (containing $35 \mathrm{mg}$ of immobilized galactose oxidase, $35 \mathrm{mg}$ of immobilized catalase and $35 \mathrm{mg}$ of immobilized horseradish peroxidase) or free tri-enzymes (20 U of galactose oxidase, $8000 \mathrm{U}$ of catalase and $500 \mathrm{U}$ of horseradish peroxidase); $200 \mathrm{mM}$ of HMF; Tris- $\mathrm{HCl}$ buffer $(50 \mathrm{mM}, \mathrm{pH}$ 6.6) for co-immobilized tri-enzymes and separately immobilized tri-enzymes, and Tris- $\mathrm{HCl}$ buffer $(50 \mathrm{mM}, \mathrm{pH} 7.1)$ for free tri-enzymes; at $37^{\circ} \mathrm{C}$.

\subsection{Comparison of DFF Yield}

The data in Table 4 confirm that co-immobilized tri-enzymes achieve an increase in DFF yield of $106 \%$ compared with separately immobilized enzymes. The free tri-enymes exhibit a low DFF yield due to the inactivation effect of HMF on its activities. One of the primary goals in the co-immobilization of different enzymes is to diminish deleterious side products [54]. The enhancement in DFF yield should be attributed to the favorable proximity effect of co-immobilized tri-enzymes, which benefits catalase by instantaneously removing $\mathrm{H}_{2} \mathrm{O}_{2}$ generated by galactose oxidase on the same matrix during HMF oxidation. In Guisan and his co-workers' report, glycerol dehydrogenase, NADH oxidase and catalase were co-immobilized on agarose beads to accomplish the selective oxidation of glycerol to 1,3-dihydroxyacetone, and the co-immobilized tri-enzyme system achieved an increase in the product yield of $190 \%$ compared with a separately immobilized tri-enzyme system, owing to in situ elimination of $\mathrm{H}_{2} \mathrm{O}_{2}$ [42], which is in accordance with our results. $\mathrm{Cu}_{3}(\mathrm{PO})_{4}$ crystals have no catalytic activity for the oxidation of HMF.

Table 4. Comparison of the DFF yield of co-immobilized enzymes and independently immobilized enzymes.

\begin{tabular}{cc}
\hline Samples & Yield (\%) \\
\hline Co-immobilized tri-enzymes $^{\mathrm{a}}$ & $95.7 \pm 2.7$ \\
Immobilized enzymes independently $^{\mathrm{b}}$ & $90.4 \pm 1.9$ \\
Free tri-enzymes $^{\mathrm{c}}$ & $53.8 \pm 2.3$ \\
The nanoflower matrix & $\mathrm{ND}$ \\
\hline
\end{tabular}

a Reaction conditions: $35 \mathrm{mg}$ of co-immobilized tri-enzymes; $200 \mathrm{mM}$ of HMF; $37^{\circ} \mathrm{C}$; Tris- $\mathrm{HCl}$ buffer $(50 \mathrm{mM}$, pH 6.6). ${ }^{\mathrm{b}}$ Reaction conditions: $35 \mathrm{mg}$ of immobilized galactose oxidase, $35 \mathrm{mg}$ of immobilized catalase and $35 \mathrm{mg}$ of immobilized horseradish peroxidase; $200 \mathrm{mM}$ of HMF; $37^{\circ} \mathrm{C}$; Tris- $\mathrm{HCl}$ buffer $\left(50 \mathrm{mM}, \mathrm{pH}\right.$ 6.6). ${ }^{\mathrm{c}}$ Reaction conditions: Free tri-enzymes ( $20 \mathrm{U}$ of galactose oxidase, $8000 \mathrm{U}$ of catalase and $500 \mathrm{U}$ of horseradish peroxidase); $200 \mathrm{mM}$ of $\mathrm{HMF} ; 37^{\circ} \mathrm{C}$; Tris- $\mathrm{HCl}$ buffer (50 mM, pH 6.6).

\subsection{Reusability of Co-Immobilized Tri-Enzymes}

One of the primary advantages of the utilization of immobilization enzyme techniques is the potential for reuse of the enzyme [55-58]. The operational stability of co-immobilized tri-enzymes is illustrated in Figure 7. The co-immobilized tri-enzymes still maintain $86 \%$ of the initial yield, even after 30 runs. After each run, the reaction system was centrifuged, and no absorbance at $\mathrm{OD}_{280} \mathrm{~nm}$ in the resulting suspension was detected by UV-vis spectrophotometer, confirming that 
no leakage of enzymes in the nanoflower matrix occurred. Hence, the repeated reaction, separation and rinsing steps in successive reactions may give rise to a slight loss of DFF yield. The outstanding reusability can be attributed to: (1) the stable conjunction between the tri-enzymes and the hybrid nanoflowers via the coordinate bond between the three enzymes and $\mathrm{Cu}$ ions in the nanoflowers, (2) the enhanced rigidification of the tri-enzymes' tertiary structure by immobilization, and (3) the remarkable mechanical stability of the $\mathrm{Cu}_{3}\left(\mathrm{PO}_{4}\right)_{2}$ nanoflower matrix, which was demonstrated by our previous works in which lipase-incorporated nanoflowers retained $98.7 \%$ of the initial enzyme activity and $95.6 \%$ of the initial $E$ value after 10 continuous batches for resolution of $(R, S)-2$-pentanol and laccase, and in other nanoflowers $93.2 \%$ of the initial activity for synthesizing viniferin was maintained after 10 consecutive runs $[59,60]$. The perfect reusability of co-immobilized tri-enzymes permits their industrial amplification potential for producing DFF.

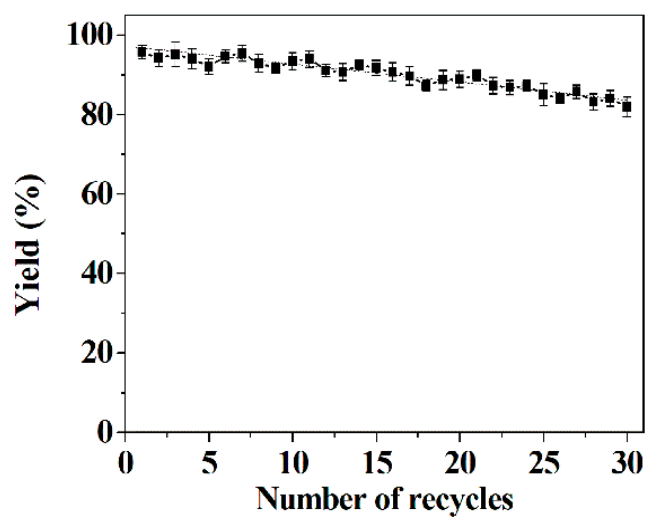

Figure 7. Reusability of co-immobilized tri-enzymes. Reaction conditions of each run: $35 \mathrm{mg}$ of co-immobilized tri-enzymes; $200 \mathrm{mM}$ of $\mathrm{HMF} ; 37^{\circ} \mathrm{C}$; Tris- $\mathrm{HCl}$ buffer (50 mM, pH 6.6).

\subsection{Determination of the Level of $\mathrm{H}_{2} \mathrm{O}_{2}$ in Different Reaction Systems}

The level of hydrogen peroxide released during the enzymatic process was measured with soluble, either immobilized separately or co-immobilized, biocatalysts. The results confirm that $2.5 \pm 0.4 \mu \mathrm{m}$ of $\mathrm{H}_{2} \mathrm{O}_{2}$ could be detected in the reaction solution when the co-immobilized tri-enzymes were used as catalysts, while $27.2 \pm 2.2 \mu \mathrm{m}$ of $\mathrm{H}_{2} \mathrm{O}_{2}$ was found in the reaction mixture when the independently immobilized tri-enzymes were employed, and $253.3 \pm 3.7 \mu \mathrm{m} \mathrm{of} \mathrm{H}_{2} \mathrm{O}_{2}$ was present in the reaction system catalyzed by free tri-enzymes (Table 5). Guisan et al. demonstrated that a co-immobilized three enzymes system made up of glycerol dehydrogenase, NADH oxidase, and catalase exhibited a $115 \%$ increase in efficiency of $\mathrm{H}_{2} \mathrm{O}_{2}$ elimination in comparison with separately immobilized enzymes, which is in agreement with our results [42]. The higher $\mathrm{H}_{2} \mathrm{O}_{2}$ removal capability of co-immobilized tri-enzymes compared with independently immobilized tri-enzymes confirms the existence of a proximity effect between the galactose oxidase and catalase on the same carrier. The lower $\mathrm{H}_{2} \mathrm{O}_{2}$ removal capability of free tri-enzymes as compared with other catalysts is due to the inactive effect of $\mathrm{HMF}$ at a higher concentration on the activity of free catalase.

Table 5. Comparison of the level of $\mathrm{H}_{2} \mathrm{O}_{2}$ produced during the oxidation of HMF catalyzed by free galactose oxidase, independently immobilized galactose oxidase, and co-immobilized galactose oxidase.

\begin{tabular}{cc}
\hline Catalysts & $\begin{array}{c}\text { The Concentration of } \mathrm{H}_{\mathbf{2}} \mathrm{O}_{\mathbf{2}} \text { Produced from the } \\
\text { Oxidation of } \mathrm{HMF}(\boldsymbol{\mu m})\end{array}$ \\
\hline Free tri-enzymes & $253.3 \pm 3.7$ \\
Independently immobilized tri-enzymes & $27.2 \pm 2.2$ \\
Co-immobilized tri-enzymes & $2.5 \pm 0.4$ \\
\hline
\end{tabular}




\section{Materials and Methods}

\subsection{Materials}

Galactose oxidase from Dactylium dendroides (500-1500 U/mg protein, one unit generates a $\Delta \mathrm{A} 425$ of 1.0 per minute at $\mathrm{pH} 6.0$ at $25^{\circ} \mathrm{C}$ in a peroxidase and o-tolidine system), catalase from bovine liver (2000-5000 U/mg protein, one unit decomposes to 1.0 micromole of hydrogen peroxide per minute at $\mathrm{pH} 7.0$ at $\left.25^{\circ} \mathrm{C}\right)$, horseradish peroxidase $(>200 \mathrm{U} / \mathrm{mg}$ protein, one unit offers $1.0 \mathrm{mg}$ purpurogallin from pyrogallolin after $20 \mathrm{sec}$ at $\mathrm{pH} 6.0$ at $20^{\circ} \mathrm{C}$ ), $\mathrm{HMF}, \mathrm{KBr}$, bovine serum albumin (BSA), choline chloride, and glycerol were obtained from Sigma-Aldrich Chemical Co. (St. Louis, MO, USA). 3-Methoxybenzyl alcohol, hydrogen peroxide solution (30 wt \% in $\mathrm{H}_{2} \mathrm{O}$ ), pyrogallol, hydroxymethylfurfural (HMF), 2,5-diformylfuran (DFF), and SIGMAFAST DAB with Metal Enhancer Tablet Sets (DAB) were also supplied by Sigma-Aldrich Chemical Co. All chemicals and reagents were of analytical grade. All aqueous solutions were prepared with Milli-Q water.

\subsection{Co-Immobilization of Tri-Enzymes}

The co-immobilization procedure of tri-enzymes is similar to the one described in previous work [30]. Taking in account that the best DFF yield could be obtained when using soluble galactose oxidase (10 U), catalase (4000 U) and horseradish peroxidase (250 U) as catalysts in deionized water [23], the three enzymes were added to the immobilization system according to the abovementioned ratio. In brief, $650 \mathrm{U}$ of galactose oxidase, $260 \mathrm{KU}$ of catalase and $16.25 \mathrm{KU}$ of horseradish peroxidase were dissolved in $3 \mathrm{~L}$ of PBS buffer $(50 \mathrm{mmol} / \mathrm{L}, \mathrm{pH} 7.4)$, before $20 \mathrm{~mL}$ of $\mathrm{CuSO}_{4}(120 \mathrm{mM})$ was added. The proportion of the three enzymes in the co-immobilized preparation was 0.01:1.1:1.3. The mixture was incubated at $4{ }^{\circ} \mathrm{C}$ for 3 days. Then, the blue product was harvested by centrifugation at $3500 \times g$ for $20 \mathrm{~min}$, and then rinsed with deionized water. Finally, the product was dried at room temperature. The Bradford protein assay was used to determine the protein concentration in the supernatant and washing solutions, and BSA was used as standard [61]. The immobilization yields (\%) of the tri-enzymes and separately immobilized enzymes were calculated by the formula below:

$$
\mathrm{Y}_{1}=\left(\left(\mathrm{W}_{1}-\mathrm{W}_{2}\right) / \mathrm{W}_{1}\right) \times 100
$$

where $Y_{1}=$ encapsulation yield (\%), $W_{1}=$ the amount of the enzymes employed in immobilization system, and $W_{2}=$ the amount of the enzymes present in the supernatant and washing solutions. Herein, the immobilization yield of the tri-enzymes was $96 \%$.

The procedures for the independently immobilized enzymes were the same as for the co-immobilization route, except that only one enzyme and BSA, which was employed to replace the two other enzymes, were co-immobilized into the nanoflowers. The immobilization yield of separately immobilized enzymes was also $96 \%$.

\subsection{Characteristics of Co-Immobilized Tri-Enzymes}

Scanning electron microscopy (SEM) images were taken using a JSM-6700F electron microscope (JEOL, Tokyo, Japan) operated at $30 \mathrm{kV}$. Fourier-transform infrared spectroscopy (FTIR) spectra were recorded on a 5700 FTIR spectrometer (Nicolet, Madison, WI, USA) using KBr pellets at a resolution of $4 \mathrm{~cm}^{-1}$.

\subsection{Enzyme Assay}

\subsubsection{Galactose Oxidase}

The activities of free galactose oxidase, co-immobilized galactose oxidase, and independently immobilized galactose oxidase were measured using 3-methoxybenzyl alcohol as the substrate [26]. The oxidation of 3-methoxybenzyl alcohol was triggered by the addition of a suitable amount of 
catalyst sample (50 mg of co-immobilized galactose oxidase, $50 \mathrm{mg}$ of independently immobilized galactose oxidase, or $100 \mu \mathrm{L}$ of $0.3 \mathrm{mg} / \mathrm{mL}$ free galactose oxidase solution prepared by Tris-HCL ( $50 \mathrm{mM}$, $\mathrm{pH} 7.1)$ ) to $10 \mathrm{~mL}$ of $0.06 \mathrm{M}$ 3-methoxybenzyl alcohol dissolved in the same buffer. The reaction systems were incubated at $37^{\circ} \mathrm{C}$ for $3 \mathrm{~min}$. For co-immobilized galactose oxidase and independently immobilized galactose oxidase, the aliquots of the reaction mixture $(1 \mathrm{~mL})$ were taken every $30 \mathrm{~s}$ and then filtrated by a membrane filter $(0.22 \mu \mathrm{m}$ pore size). The absorbance increase of the filtrate at $314 \mathrm{~nm}$ $\left(\varepsilon=2691 \mathrm{M}^{-1} \mathrm{~cm}^{-1}\right.$ ) was recorded using an 8453 UV-VIS spectrophotometer (Agilent, Santa Clara, CA, USA). The determination of the activity of free enzymes followed the same procedure, except that the filtration step was omitted. One unit was defined as the amount of enzyme that formed $1.0 \mu$ mol of aldehyde per minute per milligram of galactose oxidase located in the hybrid nanoflowers, or free galactose oxidase under the conditions described.

\subsubsection{Catalase}

The activities of free catalase, co-immobilized catalase, and independently immobilized catalase were determined by following the decomposition of $\mathrm{H}_{2} \mathrm{O}_{2}$ [62]. The hybrid nanoflowers containing enzymes $(5 \mathrm{mg}$ ) were suspended in $50 \mathrm{~mL}$ of deionized water and allowed to stand for $5 \mathrm{~min}$. A suitable amount of catalyst sample $(100 \mu \mathrm{L}$ of $0.1 \mathrm{mg} / \mathrm{mL}$ co-immobilized catalase, $100 \mu \mathrm{L}$ of $0.1 \mathrm{mg} / \mathrm{mL}$ independently immobilized catalase, or $100 \mu \mathrm{L}$ of $0.01 \mathrm{mg} / \mathrm{mL}$ free catalase) was added to $10 \mathrm{~mL}$ of $12 \mathrm{mM} \mathrm{H}_{2} \mathrm{O}_{2}$ to start the decomposition reaction. The separation of co-immobilized catalase and independently immobilized catalase from the reaction media was carried out by the filtration steps described above. The absorbance decrease of filtrate at $240 \mathrm{~nm}\left(\varepsilon=43.6 \mathrm{M}^{-1} \mathrm{~cm}^{-1}\right)$ was monitored using the Agilent 8453 UV-VIS spectrophotometer. The determination of the activity of free enzymes followed the same procedure, but without the filtration step. One unit was defined as the amount of enzyme that decomposed $1.0 \mu \mathrm{mol}$ of $\mathrm{H}_{2} \mathrm{O}_{2}$ per minute per milligram of catalase encapsulated into the hybrid nanoflowers, or free catalase under the conditions described.

\subsubsection{Horseradish Peroxidase}

The activities of free horseradish peroxidase, co-immobilized horseradish peroxidase, and independently immobilized horseradish peroxidase were assayed using pyrogallol and $\mathrm{H}_{2} \mathrm{O}_{2}$ as substrates [63]. The reaction mixture contained: $100 \mathrm{mM}$ phosphate buffer, $\mathrm{pH} 6.0,10 \mathrm{mM} \mathrm{H}_{2} \mathrm{O}_{2}$ and $13 \mathrm{mM}$ pyrogallol, and a suitable amount of catalyst sample $(100 \mu \mathrm{L}$ of $0.1 \mathrm{mg} / \mathrm{mL}$ co-immobilized horseradish peroxidase, $100 \mu \mathrm{L}$ of $0.1 \mathrm{mg} / \mathrm{mL}$ independently immobilized horseradish peroxidase or $100 \mu \mathrm{L}$ of $0.01 \mathrm{mg} / \mathrm{mL}$ free horseradish peroxidase) in a final volume of $20 \mathrm{~mL}$. The reaction mixture was incubated at $30^{\circ} \mathrm{C}$ for $3 \mathrm{~min}$. The absorbance increase at $430 \mathrm{~nm}\left(\varepsilon=2.47 \mathrm{mM}^{-1} \mathrm{~cm}^{-1}\right)$ was detected using the Agilent 8453 UV-VIS spectrophotometer. As mentioned above, co-immobilized horseradish peroxidase and independently immobilized horseradish peroxidase were separated by a filtration step to complete the UV-VIS detection. One unit was defined as the amount of enzyme that produced $1.0 \mu$ mol of purpurogallin per minute per milligram of horseradish peroxidase encapsulated into the hybrid nanoflowers, or free horseradish peroxidase.

\subsection{Kinetic Analysis}

Comparison of the Michaelis-Menten constants $K m$ and $V \max$ of the soluble enzymes, the enzymes in co-immobilized tri-enzymes, and independently immobilized enzymes were implemented. The effect of substrate concentration on the initial rates of different catalysts was determined via the spectrophotometric method using the assays described in Section 3.4. As for galactose oxidase, the concentration of 3-methoxybenzyl alcohol in Tris-HCL ( $50 \mathrm{mM}, \mathrm{pH} 7.1$ ) was varied from 3 to $60 \mathrm{mM}$. For catalase, the concentration of $\mathrm{H}_{2} \mathrm{O}_{2}$ was varied from 5 to $60 \mathrm{mM}$. For horseradish peroxidase, the concentration of pyrogallol in $100 \mathrm{mM}$ phosphate buffer was varied from 1 to $8 \mathrm{mM}$. After acquiring the initial rates of different catalysts versus their substrate concentration data, the values of $V \max$ 
and $\mathrm{Km}$ could be calculated through non-linear regression using the Origin software 8.5 software (OriginLab, Northampton, MA, USA).

\subsection{Oxidation of HMF by Co-Immobilized Tri-Enzymes}

The oxidation reaction of HMF was conducted by mixing $35 \mathrm{mg}$ of co-immobilized tri-enzymes and $5 \mathrm{~mL}$ of $200 \mathrm{mM}$ HMF prepared by $50 \mathrm{mM}$ Tris- $\mathrm{HCl}$ buffer ( $\mathrm{pH}$ 6.6) in a vessel covered to prevent evaporation. The resulting mixture was consecutively stirred in a shaking bath at $160 \mathrm{rpm}$ at $37^{\circ} \mathrm{C}$ for 7 days. The resulting mixture was treated by air bubbling for 15 min each day. After centrifugation at $3500 \times g$ for $5 \mathrm{~min}, 5 \mathrm{~mL}$ of ethyl acetate was added to the supernatant. The obtained mixture was extracted using $5 \mathrm{~mL}$ of deep eutectic solvent (choline chloride: glycerol $(1: 2, \mathrm{~mol} / \mathrm{mol})$ ) three times. The obtained mixture stood for $10 \mathrm{~min}$ at $25^{\circ} \mathrm{C}$ to form a biphasic system. The HMF and DFF could be found in the upper and lower phases, respectively. Their amounts were determined by HPLC analysis. The DFF yield was calculated according to the following formula:

$$
\mathrm{Y}_{2}=\left(\mathrm{W}_{3} / \mathrm{W}_{4}\right) \times 100
$$

where $Y_{2}=$ DFF yield $(\%), W_{3}=$ the amount of DFF, and $W_{4}=$ the amount of HMF.

\subsection{HPLC Analysis}

Analyses of HMF and DFF were implemented by RP-HPLC using Waters 1525 Binary Pumps and a Waters 2489 UV-Visible detector (Waters, Milford, MA, USA) on a Zorbax SB C-18 column ( $250 \mathrm{~mm} \times 4.6 \mathrm{~mm}, 5 \mu \mathrm{m}$, Agilent) The mobile phase consisted of acetonitrile and $0.1 \mathrm{wt} \%$ trifluoroacetic acid aqueous solution $(v / v=15: 85)$ at $0.8 \mathrm{~mL} / \mathrm{min}$. The column oven temperature was maintained at $35^{\circ} \mathrm{C}$. The UV detection wavelength was $284 \mathrm{~nm}$. Under these conditions, the retention times of HMF and DFF were 5.1 and $6.9 \mathrm{~min}$, respectively.

\subsection{Thermal Stability}

Suitable amounts of soluble tri-enzymes were dissolved in sodium Tris-HCL buffer $(50 \mathrm{mM}$, pH 7.1) and co-immobilized tri-enzymes and separately immobilized tri-enzymes were dissolved in sodium Tris-HCL buffer ( $50 \mathrm{mM}, \mathrm{pH}$ 6.6), respectively, and then the resulting mixtures were incubated at different temperatures ranging from 35 to $75^{\circ} \mathrm{C}$ for $2 \mathrm{~h}$. Then, the treated tri-enzymes were assessed in terms of the oxidation of HMF. The DFF yields of soluble tri-enzymes, separately immobilized tri-enzymes, and co-immobilized tri-enzymes were examined to assess their thermal stability. The relative yield (\%) was calculated by the ratio of the residual DFF yield to the initial DFF yield of each sample.

\subsection{Reusability}

After each cycle, co-immobilized tri-enzymes were separated from the reaction mixture by centrifugation at $3500 \times g$ for $3 \mathrm{~min}$, washed with deionized water three times, and dried at $65^{\circ} \mathrm{C}$ in a vacuum oven. The resulting powder was used in the next run under the same conditions. The residual DFF yield of the recycled co-immobilized tri-enzymes was calculated each run by considering the initial DFF yield to be $100 \%$.

\subsection{Determination of the Level of $\mathrm{H}_{2} \mathrm{O}_{2}$ Produced during the Oxidation Reaction}

The $\mathrm{DAB} / \mathrm{HRP}$ method with slight modification was adopted to measure the quantification of released $\mathrm{H}_{2} \mathrm{O}_{2}$ in the reaction mixture [64]. During the oxidation reaction, the aliquots of the reaction mixture $(1 \mathrm{~mL})$ were taken every 1 day, and then filtrated by a membrane filter $(0.22 \mu \mathrm{m}$ pore size). A suitable amount of DAB and HRP was added to the filtrate, and then the absorbance increase of filtrate at $460 \mathrm{~nm}$ was recorded by an Agilent 8453 UV-VIS spectrophotometer. The absorbance at $460 \mathrm{~nm}$ was compared to a standard curve, which was prepared separately using different known 
concentrations of $\mathrm{H}_{2} \mathrm{O}_{2}$. The $\mathrm{H}_{2} \mathrm{O}_{2}$ concentration value was the mean for data obtained during the oxidation reaction.

\subsection{Statistical Analysis}

The data expressed in various studies were plotted using Origin 8.5 and expressed as the standard error $( \pm)$. Each value represents the mean for three independent experiments.

\section{Conclusions}

In summary, galactose oxidase, catalase and horseradish peroxidase were immobilized into $\mathrm{Cu}_{3}\left(\mathrm{PO}_{4}\right)_{2}$ nanoflowers to resist the oxidative damage aroused by the hydroxymethylfurfural substrate at a high concentration. Although these three enzymes after co-immobilization do not have advantages in activity and kinetic parameters in their model substrate assay compared with their free counterparts, co-immobilized tri-enzymes manifest a substantial improvement in tolerance towards the inactivation effect caused by hydroxymethylfurfural at a high concentration. The 2,5-diformylfuran yield of co-immobilized tri-enzymes is superior to that of free tri-enzymes after incubating at different temperatures ranging from 35 to $75{ }^{\circ} \mathrm{C}$, confirming the remarkably enhanced thermal stability of co-immobilized tri-enzymes. Moreover, co-immobilized tri-enzymes show better performance in the conversion of hydroxymethylfurfural to 2,5-diformylfuran as compared with independently immobilized enzymes, demonstrating the role of physical proximity of galactose oxidase and catalase on the same support. After 30 cycles, co-immobilized tri-enzymes still retain $86 \%$ of the initial yield. A comparison in the level of released $\mathrm{H}_{2} \mathrm{O}_{2}$ revealed that the physical proximity effect of active sites of different enzymes on the same carrier is important. This is beneficial to the combination comprised of these three enzymes to exert their catalytic activity, even in the presence of $200 \mathrm{mM}$ hydroxymethylfurfural. A large number of chemical catalysts have been employed to fulfill the conversion of lignocellulosic biomass to hydroxymethylfurfural. We predict that the combination of chemical catalysts and co-immobilized tri-enzymes explored in this paper would enable the conversion of lignocellulosic biomass to 2,5-diformylfuran. The superior stability and perfect reusability of co-immobilized tri-enzymes would allow us to further explore its potential in lignocellulosic biomass conversion.

Author Contributions: Conceptualization, Z.W. and G.C.; Data curation, X.Y.; Formal analysis, L.S.; Funding acquisition, G.C.; Investigation, Z.W.; Methodology, Z.W.; Project administration, G.C.; Resources, G.C.; Software, L.S.; Supervision, G.C.; Validation, L.S., X.Y. and S.Z.; Visualization, S.Z.; Writing-original draft, Z.W.; Writing-review \& editing, G.C.

Funding: This work was supported financially by the key laboratory of straw biology and utilization Foundation of China (2019(39)) and China Scholarship Council (CSC, File No. 201808220076).

Conflicts of Interest: The authors declare no conflict of interest.

\section{References}

1. Ordomsky, V.V.; Van Der Schaaf, J.; Schouten, J.C.; Nijhuis, T.A. Fructose Dehydration to 5Hydroxymethylfurfural over Solid Acid Catalysts in a Biphasic System. ChemSusChem 2012, 5, 1812-1819. [CrossRef] [PubMed]

2. Wang, T.; Nolte, M.W.; Shanks, B.H. Catalytic dehydration of C6carbohydrates for the production of hydroxymethylfurfural (HMF) as a versatile platform chemical. Green Chem. 2014, 16, 548-572. [CrossRef]

3. Bozell, J.J.; Petersen, G.R. Technology development for the production of biobased products from biorefinery carbohydrates-the US Department of Energy's “Top 10" revisited. Green Chem. 2010, 12, 539. [CrossRef]

4. Del Poeta, M.; Schell, W.A.; Dykstra, C.C.; Jones, S.; Tidwell, R.R.; Czarny, A.; Bajic, M.; Bajic, M.; Kumar, A.; Boykin, D.; et al. Structure-In Vitro Activity Relationships of Pentamidine Analogues and Dication-Substituted Bis-Benzimidazoles as New Antifungal Agents. Antimicrob. Agents Chemother. 1998, 42, 2495-2502. [CrossRef] 
5. Hopkins, K.T.; Wilson, W.D.; Bender, B.C.; McCurdy, D.R.; Hall, J.E.; Tidwell, R.R.; Kumar, A.; Bajic, M.; Boykin, D.W. Extended aromatic furan amidino derivatives as anti-Pneumocystis carinii agents. J. Med. Chem. 1998, 41, 3872-3878. [CrossRef] [PubMed]

6. Richter, D.T.; Lash, T.D. Oxidation with dilute aqueous ferric chloride solutions greatly improves yields in the '4+ 1'synthesis of sapphyrins. Tetrahedron Lett. 1999, 40, 6735-6738. [CrossRef]

7. Takimiya, K.; Otsubo, T.; Ogura, F.; Ashitaka, H.; Morita, K.; Suehiro, T. Pyranylidenemethyl- and Thiopyranylidenemethyl-substituted Furans, Thiophenes, and N-Methylpyrroles as Precursors of Organic Metals and Third-order Nonlinear Optical Materials. Chem. Lett. 1994, 23, 255-258. [CrossRef]

8. Gandini, A.; Belgacem, N.M. Recent advances in the elaboration of polymeric materials derived from biomass components. Polym. Int. 1998, 47, 267-276. [CrossRef]

9. Gandini, A. Furans in polymer chemistry. Prog. Polym. Sci. 1997, 22, 1203-1379. [CrossRef]

10. Sheibley, D.W. Cross-Linked Polyvinyl Alcohol Films as Alkaline Battery Separators. J. Electrochem. Soc. 1983, 130, 255. [CrossRef]

11. Daub, J.; Salbeck, J.; Knöchel, T.; Fischer, C.; Kunkely, H.; Rapp, K.M. Light-Sensitive Molecular Building Blocks with Electron Transfer Activity: Synthesis and Properties of a Photochemically Switchable, Dicyanovinyl-Substituted Furan. Angew. Chem. Int. Ed. 1989, 28, 1494-1496. [CrossRef]

12. Van Putten, R.-J.; Van Der Waal, J.C.; De Jong, E.; Rasrendra, C.B.; Heeres, H.J.; De Vries, J.G. Hydroxymethylfurfural, A Versatile Platform Chemical Made from Renewable Resources. Chem. Rev. 2013, 113, 1499-1597. [CrossRef] [PubMed]

13. Cottier, L.; Descotes, G.; Lewkowski, J.; Skowronski, R. ULTRASONICALLY ACCELERATED SYNTHESES OF FURAN-24-DICARBALDEHYDE FROM 5-HYDROXYMETHYL-2-FURFURAL. Org. Prep. Proced. Int. 1995, 27, 564-566. [CrossRef]

14. Amarasekara, A.S.; Green, D.; McMillan, E. Efficient oxidation of 5-hydroxymethylfurfural to 2,5-diformylfuran using Mn(III)-salen catalysts. Catal. Commun. 2008, 9, 286-288. [CrossRef]

15. Yoon, H.-J.; Choi, J.-W.; Jang, H.-S.; Cho, J.K.; Byun, J.-W.; Chung, W.-J.; Lee, S.-M.; Lee, Y.-S. Selective oxidation of 5-hydroxymethylfurfural to 2, 5-diformylfuran by polymer-supported IBX amide. Synlett 2011, 2011, 165-168.

16. Hodgson, E.K.; Fridovich, I. Interaction of bovine erythrocyte superoxide dismutase with hydrogen peroxide. Inactivation of the enzyme. Biochem. 1975, 14, 5294-5299. [CrossRef] [PubMed]

17. Navarro, O.C.; Canós, A.C.; Chornet, S.I. Chemicals from Biomass: Aerobic Oxidation of 5-Hydroxymethyl2-Furaldehyde into Diformylfurane Catalyzed by Immobilized Vanadyl-Pyridine Complexes on Polymeric and Organofunctionalized Mesoporous Supports. Top. Catal. 2009, 52, 304-314. [CrossRef]

18. Carlini, C.; Patrono, P.; Galletti, A.M.R.; Sbrana, G.; Zima, V. Selective oxidation of 5-hydroxymethyl-2furaldehyde to furan-2,5-dicarboxaldehyde by catalytic systems based on vanadyl phosphate. Appl. Catal. A Gen. 2005, 289, 197-204. [CrossRef]

19. Ma, J.; Du, Z.; Xu, J.; Chu, Q.; Pang, Y. Efficient Aerobic Oxidation of 5-Hydroxymethylfurfural to 2, 5-Diformylfuran, and Synthesis of a Fluorescent Material. ChemSusChem 2011, 4, 51-54. [CrossRef]

20. De María, P.D.; Guajardo, N. Biocatalytic Valorization of Furans: Opportunities for Inherently Unstable Substrates. ChemSusChem 2017, 10, 4123-4134. [CrossRef]

21. McKenna, S.M.; Herter, S.; Turner, N.J.; Leimkühler, S.; Carnell, A.J. Enzyme cascade reactions: synthesis of furandicarboxylic acid (FDCA) and carboxylic acids using oxidases in tandem. Green Chem. 2015, 17, 3271-3275. [CrossRef]

22. Van Deurzen, M.P.; Van Rantwijk, F.; Sheldon, R.A. Chloroperoxidase-Catalyzed Oxidation of 5-Hydroxymethylfurfural. J. Carbohydr. Chem. 1997, 16, 299-309. [CrossRef]

23. Qin, Y.-Z.; Li, Y.-M.; Zong, M.-H.; Wu, H.; Li, N. Enzyme-catalyzed selective oxidation of 5-hydroxymethylfurfural (HMF) and separation of HMF and 2,5-diformylfuran using deep eutectic solvents. Green Chem. 2015, 17, 3718-3722. [CrossRef]

24. Whittaker, M.M.; Whittaker, J.W. The active site of galactose oxidase. J. Boil. Chem. 1988, 263, 6074-6080.

25. Aebi, H. Catalase. In Methods of enzymatic analysis; Bergmeyer, H.U., Ed.; Elsevier: Amsterdam, The Netherlands, 1974; Volume 1974, pp. 673-684.

26. Tressel, P.; Kosman, D.J. o,o-Dityrosine in native and horseradish peroxidase-activated galactose oxidase. Biochem. Biophys. Res. Commun. 1980, 92, 781-786. [CrossRef] 
27. Modig, T.; Liden, G.; Taherzadeh, M.J. Inhibition effects of furfural on alcohol dehydrogenase, aldehyde dehydrogenase and pyruvate dehydrogenase. Biochem. J. 2002, 363, 769-776. [CrossRef] [PubMed]

28. Taherzadeh, M.J.; Gustafsson, L.; Niklasson, C.; Liden, G.; Taherzadeh, M. Physiological effects of 5-hydroxymethylfurfural on Saccharomyces cerevisiae. Appl. Microbiol. Biotechnol. 2000, 53, 701-708. [CrossRef]

29. Mateo, C.; Palomo, J.M.; Fernandez-Lorente, G.; Guisan, J.M.; Fernandez-Lafuente, R. Improvement of enzyme activity, stability and selectivity via immobilization techniques. Enzym. Microb. Technol. 2007, 40, 1451-1463. [CrossRef]

30. Ge, J.; Lei, J.; Zare, R.N. Protein-inorganic hybrid nanoflowers. Nat. Nanotechnol. 2012, 7, 428-432. [CrossRef]

31. Garcia-Galan, C.; Berenguer-Murcia, Á.; Fernandez-Lafuente, R.; Rodrigues, R.C. Potential of Different Enzyme Immobilization Strategies to Improve Enzyme Performance. Adv. Synth. Catal. 2011, 353, 2885-2904. [CrossRef]

32. Arana-Peña, S.; Mendez-Sanchez, C.; Rios, N.S.; Ortiz, C.; Gonçalves, L.R.; Fernandez-Lafuente, R. New applications of glyoxyl-octyl agarose in lipases co-immobilization: Strategies to reuse the most stable lipase. Int. J. Boil. Macromol. 2019, 131, 989-997. [CrossRef] [PubMed]

33. Rueda, N.; Bartolome-Cabrero, R.; Peirce, S.; Virgen-Ortiz, J.J.; Tacias-Pascacio, V.G.; Fernandez-Lopez, L.; Russo, M.E.; Marzocchella, A.; Fernandez-Lafuente, R. Development of simple protocols to solve the problems of enzyme coimmobilization. Application to coimmobilize a lipase and a $\beta$-galactosidase. RSC Adv. 2016, 6, 61707-61715.

34. Zaak, H.; Kornecki, J.F.; Siar, E.-H.; Fernandez-Lopez, L.; Corberán, V.C.; Sassi, M.; Fernandez-Lafuente, R. Coimmobilization of enzymes in bilayers using pei as a glue to reuse the most stable enzyme: Preventing pei release during inactivated enzyme desorption. Process. Biochem. 2017, 61, 95-101. [CrossRef]

35. Rios, N.S.; Arana-Peña, S.; Mendez-Sanchez, C.; Ortiz, C.; Gonçalves, L.R.B.; Fernandez-Lafuente, R. Reuse of Lipase from Pseudomonas fluorescens via Its Step-by-Step Coimmobilization on Glyoxyl-Octyl Agarose Beads with Least Stable Lipases. Catalysts 2019, 9, 487. [CrossRef]

36. López-Gallego, F.; Schmidt-Dannert, C. Multi-enzymatic synthesis. Curr. Opin. Chem. Boil. 2010, 14, $174-183$. [CrossRef] [PubMed]

37. Fernandez-Lafuente, R.; Rodríguez, V.; Guisán, J.M. The coimmobilization of d-amino acid oxidase and catalase enables the quantitative transformation of $\mathrm{d}$-amino acids (d-phenylalanine) into $\alpha$-keto acids (phenylpyruvic acid). Enzym. Microb. Technol. 1998, 23, 28-33. [CrossRef]

38. Batencor, L.; Hidalgo, A.; Mateo, C.; Guisan, J.M.; Lopez-Gallego, F.; Fernandez-Lafuente, R. One-Pot Conversion of Cephalosporin C to 7-Aminocephalosporanic Acid in the Absence of Hydrogen Peroxide. Adv. Synth. Catal. 2005, 347, 1804-1810.

39. Volpato, G.; Rodrigues, R.C.; Fernandez-Lafuente, R.; Rodrigues, R. Use of Enzymes in the Production of Semi-Synthetic Penicillins and Cephalosporins: Drawbacks and Perspectives. Curr. Med. Chem. 2010, 17, 3855-3873. [CrossRef]

40. Orrego, A.H.; Lopez-Gallego, F.; Espaillat, A.; Cava, F.; Guisan, J.M.; Rocha-Martin, J. One-step Synthesis of $\alpha$-Keto Acids from Racemic Amino Acids by A Versatile Immobilized Multienzyme Cell-free System. ChemCatChem 2018, 10, 3002-3011. [CrossRef]

41. García-García, P.; Rocha-Martin, J.; Fernández-Lorente, G.; Guisan, J.M. Co-localization of oxidase and catalase inside a porous support to improve the elimination of hydrogen peroxide: Oxidation of biogenic amines by amino oxidase from Pisum sativum. Enzym. Microb. Technol. 2018, 115, 73-80. [CrossRef]

42. Rocha-Martín, J.; Acosta, A.; Guisan, J.M.; López-Gallego, F.; Rocha-Martín, J.; Lopez-Gallego, F. Immobilizing Systems Biocatalysis for the Selective Oxidation of Glycerol Coupled to In Situ Cofactor Recycling and Hydrogen Peroxide Elimination. ChemCatChem 2015, 7, 1939-1947. [CrossRef]

43. Hussain, F.; Arana-Peña, S.; Morellon-Sterling, R.; Barbosa, O.; Braham, S.A.; Kamal, S.; Fernandez-Lafuente, R. Further Stabilization of Alcalase Immobilized on Glyoxyl Supports: Amination Plus Modification with Glutaraldehyde. Molecules 2018, 23, 3188. [CrossRef] [PubMed]

44. Rodrigues, R.C.; Ortiz, C.; Berenguer-Murcia, A.; Torres, R.T.R.; Fernandez-Lafuente, R. Modifying enzyme activity and selectivity by immobilization. Chem. Soc. Rev. 2013, 42, 6290-6307. [CrossRef] [PubMed]

45. Cho, I.-S.; Kim, D.W.; Lee, S.; Kwak, C.H.; Bae, S.-T.; Noh, J.H.; Yoon, S.H.; Jung, H.S.; Kim, D.-W.; Hong, K.S. Synthesis of $\mathrm{Cu} 2 \mathrm{PO} 4 \mathrm{OH}$ Hierarchical Superstructures with Photocatalytic Activity in Visible Light. Adv. Funct. Mater. 2008, 18, 2154-2162. [CrossRef] 
46. Yang, W.-J.; Griffiths, P.R.; Byler, D.M.; Susi, H. Protein Conformation by Infrared Spectroscopy: Resolution Enhancement by Fourier Self-Deconvolution. Appl. Spectrosc. 1985, 39, 282-287. [CrossRef]

47. Shaolin, M. Bioelectrochemical response of the polyaniline galactose oxidase electrode. J. Electroanal. Chem. 1994, 370, 135-139. [CrossRef]

48. Kizilyar, N.; Akbulut, U.; Toppare, L.; Özden, M.; Yağci, Y. Immobilization of invertase in conducting polypyrrole/polytetrahydrofuran graft polymer matrices. Synth. Met. 1999, 104, 45-50. [CrossRef]

49. Overbeeke, P.L.A.; Ottosson, J.; Hult, K.; Jongejan, J.A.; Duine, J.A. The Temperature Dependence of Enzymatic Kinetic Resolutions Reveals the Relative Contribution of Enthalpy and Entropy to Enzymatic Enantioselectivity. Biocatal. Biotransform. 1999, 17, 61-79. [CrossRef]

50. Souza, L.T.D.A.; Moreno-Perez, S.; Lorente, G.F.; Cipolatti, E.P.; De Oliveira, D.; Resende, R.R.; Pessela, B.C. Immobilization of Moniliella spathulata R25L270 Lipase on Ionic, Hydrophobic and Covalent Supports: Functional Properties and Hydrolysis of Sardine Oil. Molecules 2017, 22, 1508. [CrossRef] [PubMed]

51. Guimarães, J.R.; Giordano, R.D.L.C.; Fernandez-Lafuente, R.; Tardioli, P.W. Evaluation of Strategies to Produce Highly Porous Cross-Linked Aggregates of Porcine Pancreas Lipase with Magnetic Properties. Molecules 2018, 23, 2993. [CrossRef]

52. Verma, M.L.; Rao, N.M.; Tsuzuki, T.; Barrow, C.J.; Puri, M. Suitability of Recombinant Lipase Immobilised on Functionalised Magnetic Nanoparticles for Fish Oil Hydrolysis. Catalysts 2019, 9, 420. [CrossRef]

53. Tosa, T.; Mori, T.; Fuse, N.; Chibata, I. Immobilization of papain. Enzymologia 1967, 32, 153. [PubMed]

54. Ricca, E.; Brucher, B.; Schrittwieser, J.H. Multi-Enzymatic Cascade Reactions: Overview and Perspectives. Adv. Synth. Catal. 2011, 353, 2239-2262. [CrossRef]

55. Turati, D.; Morais Júnior, W.; Terrasan, C.; Moreno-Perez, S.; Pessela, B.; Fernandez-Lorente, G.; Guisan, J.; Carmona, E. Immobilization of lipase from Penicillium sp. section gracilenta (CBMAI 1583) on different hydrophobic supports: Modulation of functional properties. Molecules 2017, 22, 339. [CrossRef] [PubMed]

56. Molina-Gutiérrez, M.; Hakalin, N.L.S.; Rodríguez-Sánchez, L.; Alcaraz, L.; López, F.A.; Martínez, M.J.; Prieto, A. Effect of the Immobilization Strategy on the Efficiency and Recyclability of the Versatile Lipase from Ophiostoma piceae. Molecules 2019, 24, 1313. [CrossRef] [PubMed]

57. Sun, J.; Wang, S.; Li, W.; Li, R.; Chen, S.; Ri, H.I.; Kim, T.M.; Kang, M.S.; Sun, L.; Sun, X.; et al. Improvement of Trehalose Production by Immobilized Trehalose Synthase from Thermus thermophilus HB27. Molecules 2018, 23, 1087. [CrossRef]

58. Cohen, J.; Karav, S.; Barile, D.; de Moura Bell, J. Immobilization of an Endo- $\beta-\mathrm{N}$-acetylglucosaminidase for the Release of Bioactive N-glycans. Catalysts 2018, 8, 278. [CrossRef] [PubMed]

59. Wu, Z.; Li, X.; Li, F.; Yue, H.; He, C.; Xie, F.; Wang, Z. Enantioselective transesterification of (R, S)-2-pentanol catalyzed by a new flower-like nanobioreactor. RSC Adv. 2014, 4, 33998-34002. [CrossRef]

60. Wu, Z.; Li, H.; Zhu, X.; Li, S.; Wang, Z.; Wang, L.; Li, Z.; Chen, G. Using Laccases in the Nanoflower to Synthesize Viniferin. Catalysts 2017, 7, 188. [CrossRef]

61. Bradford, M.M. A rapid and sensitive method for the quantitation of microgram quantities of protein utilizing the principle of protein-dye binding. Anal. Biochem. 1976, 72, 248-254. [CrossRef]

62. Lartillot, S.; Kedziora, P.; Athias, A. Purification and Characterization of a New Fungal Catalase. Prep. Biochem. 1988, 18, 241-246. [CrossRef] [PubMed]

63. Chance, B.; Maehly, A. [136] Assay of catalases and peroxidases. Methods Enzymol. 1955, 2, 764-775.

64. Kengen, S.W.M.; Van Der Oost, J.; De Vos, W.M. Molecular characterization of H2O2-forming NADH oxidases from Archaeoglobus fulgidus. JBIC J. Boil. Inorg. Chem. 2003, 270, 2885-2894. [CrossRef] [PubMed]

Sample Availability: Not available. 